\title{
The international structure of a pala and a peat plateau in the Rivière Boniface region, Québec: Interferences on the formation of ice segregation mounds
}

\section{La structure interne d'une palse et d'un plateau palsique dans la région de la rivière Boniface (Québec) : implications générales pour la formation des buttes à glace de ségrégation. Die innere Struktur von einer Palse und einem Torfplateau in der Rivière Boniface-Region, Québec: Schlussfolgerungen über die Bildung von Eisabsonderungshügeln.}

\author{
Michel Allard et Luc Rousseau
}

Volume 53, numéro 3, 1999

URI : https://id.erudit.org/iderudit/004760ar

DOI : https://doi.org/10.7202/004760ar

\section{Aller au sommaire du numéro}

\section{Éditeur(s)}

Les Presses de l'Université de Montréal

ISSN

0705-7199 (imprimé)

1492-143X (numérique)

\section{Découvrir la revue}

Citer cet article

Allard, M. \& Rousseau, L. (1999). The international structure of a pala and a peat plateau in the Rivière Boniface region, Québec: Interferences on the formation of ice segregation mounds. Géographie physique et Quaternaire, 53(3), 373-387. https://doi.org/10.7202/004760ar

\section{Résumé de l'article}

La structure interne d'une palse de 5,7 $\mathrm{m}$ de haut a été étudiée à la suite d'une série de forages réalisés dans le pergélisol le long de deux profils topographiques orthogonaux. À des fins de comparaison, des forages ont aussi été réalisés sur un plateau palsique haut de seulement $1,3 \mathrm{~m}$ le long d'un profil topographique. La morphologie de la palse épouse presque la forme de son noyau de pergélisol riche en glace. La palse a grossi consécutivement à la croissance de lentilles de glace épaisses dans un sédiment de fond marin épais (Mer de Tyrrell) et de texture argilo-silteuse. Pendant la croissance de la palse et subséquemment, la couverture de sable et de tourbe a été déformée à la suite de glissements et par gélifluxion ; elle fut aussi partiellement érodée par le ruisselement et par le vent. La croissance de la palse est associée à la formation de nombreuses failles remplies de glace dans les sédiments gelés. La croissance en hauteur du plateau palsique a été limitée en raison de la formation de lentilles de glace minces dans une couche sablo-silteuse sous-jacente de seulement 1,4 m d'épaisseur; cette couche est probablement un sédiment marin intertidal. Le contexte géomorphologique quaternaire est donc à l'origine des différences de formes et de dimensions entre la palse et le plateau palsique. Les observations menées dans cette étude ont permis de déduire certaines implications générales liées à la formation des palses et des formes apparentées.
Tous droits réservés @ Les Presses de l'Université de Montréal,1999

Ce document est protégé par la loi sur le droit d'auteur. L'utilisation des services d'Érudit (y compris la reproduction) est assujettie à sa politique d'utilisation que vous pouvez consulter en ligne.

https://apropos.erudit.org/fr/usagers/politique-dutilisation/ 


\title{
THE INTERNAL STRUCTURE OF A PALSA AND A PEAT PLATEAU IN THE RIVIËRE BONIFACE REGION, QUÉBEC: INFERENCES ON THE FORMATION OF ICE SEGREGATION MOUNDS
}

\author{
Michel ALLARD* and Luc ROUSSEAU, Centre d'études nordiques, Université Laval, Sainte-Foy, Québec G1K 7 P4.
}

ABSTRACT The internal structure of a $5.7 \mathrm{~m}$ high palsa was studied through a pattern of closely spaced drill holes in permafrost along two orthogonal section lines. Holes were also drilled on a $1.3 \mathrm{~m}$ high peat plateau along a topographic transect for comparison purposes. The morphology of the palsa closely reflects the shape of the ice-rich core heaved by the growth of thick ice lenses in thick marine clay silts of the Tyrrell Sea. During and since palsa growth, the sand and peat covering was deformed by gelifluction and sliding and was also partly eroded by overland flow and wind. Palsa growth was accompanied by the formation of numerous ice-filled fault planes in the frozen sediments. The peat plateau was heaved to a lower height through the formation of thin ice lenses in an underlying layer of sandy silt only $1.4 \mathrm{~m}$ thick; this sediment is believed to be of intertidal origin. Therefore, the local Quaternary geomorphological settings are at the origin of differences in morphology and size between the palsa and the peat plateau. General inferences for the development of palsas and like landforms are made from the findings of the study.
RÉSUMÉ La structure interne d'une palse et d'un plateau palsique dans la région de la rivière Boniface (Québec) : implications générales pour la formation des buttes à glace de ségrégation. La structure interne d'une palse de 5,7 $\mathrm{m}$ de haut a été étudiée à la suite d'une série de forages réalisés dans le pergélisol le long de deux profils topographiques orthogonaux. À des fins de comparaison, des forages ont aussi été réalisés sur un plateau palsique haut de seulement 1,3 m le long d'un profil topographique. La morphologie de la palse épouse presque la forme de son noyau de pergélisol riche en glace. La palse a grossi consécutivement à la croissance de lentilles de glace épaisses dans un sédiment de fond marin épais (Mer de Tyrrell) et de texture argilo-silteuse. Pendant la croissance de la palse et subséquemment, la couverture de sable et de tourbe a été déformée à la suite de glissements et par gélifluxion ; elle fut aussi partiellement érodée par le ruisselement et par le vent. La croissance de la palse est associée à la formation de nombreuses failles remplies de glace dans les sédiments gelés. La croissance en hauteur du plateau palsique a été limitée en raison de la formation de lentilles de glace minces dans une couche sablo-silteuse sous-jacente de seulement 1,4 m d'épaisseur ; cette couche est probablement un sédiment marin intertidal. Le contexte géomorphologique quaternaire est donc à l'origine des différences de formes et de dimensions entre la palse et le plateau palsique. Les observations menées dans cette étude ont permis de déduire certaines implications générales liées à la formation des palses et des formes apparentées.

\section{ZUSAMMENFASSUNG Die innere Struktur} von einer Palse und einem Torfplateau in der Rivière Boniface-Region, Québec : Schlussfolgerungen über die Bildung von Eisabsonderungshügeln. Wir haben die innere Struktur einer $5.7 \mathrm{~m}$ hohen Palse mittels einer Serie von dicht beieinander liegenden Bohrungen in den Permafrostboden entlang von zwei orthogonalen linearen Profilen untersucht. Um zu vergleichen wurden auch Löcher in ein $1.3 \mathrm{~m}$ hohes Torfplateau entlang einem topographischen Profil gebohrt. Die Morphologie der Palse spiegelt ziemlich genau die Form des eisreichen Kerns, der durch das Anwachsen dicker Eislinsen im schweren marinen Tonschlamm des Tyrell-Meeres angehoben wurde. Während und seit dem Anwachsen der Palse wurde die Decke aus Sand und Torf durch Gelisolifluktion und Rutschung verformt, sowie teilweise durch Oberflächenwasser und Wind ausgewaschen. Paralell zum Anwachsen der Palse bildeten sich zahlreiche eisgefüllte Verwerfungsebenen in den gefrorenen Sedimenten. Das Torfplateau erreichte eine geringere Höhe durch die Bildung von Eislinsen in einer darunterliegenden Schicht von sandigem Schlamm, von nur $1.4 \mathrm{~m}$ Dicke ; man hält dies Sediment für ein Zwischengezeiten-Sediment. Der geomorphologische Kontext des Quartärs ist also für die Unterschiede in Morphologie und Größe zwischen Palse und Torfplateau verantwortlich. Die Ergebnisse der Studie erlauben allgemeine Schlüsse über die Entwicklung von Palsen und verwandten Landformen zu ziehen. 


\section{INTRODUCTION}

An abundant literature has been dedicated to palsas, peat plateaus, and related landforms until now. Palsas were defined recently in Canada as "permafrost mounds composed of alternating layers of segregation ice and peat or mineral soil" (A.C.G.R.-N.R.C., 1988). Different definitions with various contents have also been proposed; some restrict the palsas to peat bog environments (e.g. Seppälä, 1972), others include dimensional parametres and multiple modes of formation (e.g. Washburn,1983). There also exist mounds similar in size and shapes to palsas but without a peat cover. This situation lead to some terminological debate as there are mounds made of frozen peat, mounds made of frozen sediments with a peat cover and mounds made uniquely of frozen sediments. Terms such as "minerogenic palsa" (Åhman, 1976, 1977 ), "mineral palsa" (Dionne, 1978; Pissart and Gangloff, 1984), "palsa-like mound", "lithalsa" (Harris, 1993), "cryogenic mounds" (Lagarec, 1982), and "mineral permafrost mound" (Allard et al., 1986) have been used in the literature.

Small palsas up to $40-50 \mathrm{~cm}$ high and peat plateaus up to $1 \mathrm{~m}$ have been attributed to the buoyancy of frozen peat in saturated wetlands (Zoltai,1972; Outcalt and Nelson 1984, a and b). Zoltai (1972) and Zoltai and Tarnocai (1971) made a useful distinction when they showed that palsas are features that grow up to several metres as a result of the aggradation of permafrost in the mineral sediments below the peat, while most peat plateaus remain low landforms that have only a frozen core in the surface peat. However, there is a general consensus that by far the most widespread process for the formation of palsas and like landforms is frost heave resulting from the growth of segregation ice lenses in frost-sensitive fine-grained mineral sediments underlying a peat bog or a fen (Pissart, 1983; Salmi, 1970).

It has also been proposed by several authors that some palsas that occur in fields comprising many individuals are the result of the breakdown and degradation of vast high peat plateaus (Dionne, 1978; Lagarec, 1980; Washburn, 1983; Allard and Seguin, 1987). This breakdown would be a thermokarst process initiated along cracks or drainage pathways in the plateaus (Allard et al., 1996). This process of individualization of mounds from an original larger entity is well documented in a series of studies spanning 37 years on the Rivière Ouiatchouan palsa bog near Lac GuillaumeDelisle in northern Québec (Laprise and Payette, 1988; Laberge and Payette, 1995).

An abundant literature is dedicated to the vegetation cover of palsas, to the peat sequences in their coverings and to their geographic distribution relative to climatic parameters and biogeographic zones (National Wetlands Working Group, 1988; Dionne, 1984). Although most existing studies mention the presence of frozen mineral sediments under the peat and occasionnaly report some ice lenses, there is still no detailed analysis of the internal structure in the deep permafrost core of palsas and peat plateaus. As the mechanics of ice lens formation is now well understood from therorical studies, laboratory tests and mathematical models (Gilpin,

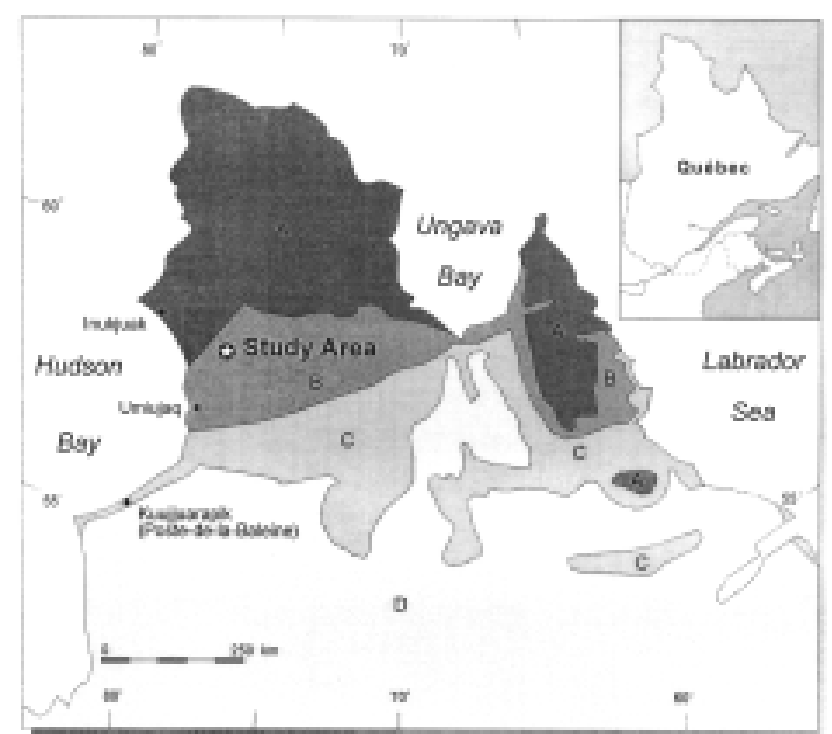

FIGURE 1. Location of the study area. A) Continuous permafrost. B) Widespread (discontinuous) permafrost. C) Scattered (discontinuous) permafrost. D) Sporadic permafrost (Allard et al. ,1993).

Localisation de la région étudiée. A) Pergélisol continu. B) Pergélisol discontinu et abondant. C) Pergélisol discontinu et dispersé. D) Pergélisol sporadique (Allard et al., 1993).

1980, see also Konrad, 1994, for a review), a wealth of new information can be gained and deductions can be drawn from the sequences and structural disposition of the ice lenses found in palsas. Frost heave is largely dependant on the type of sediments affected and on the thermal regime applied on the surface; this is what governs ice lens growth and thickness. Therefore, the spatial variability in the field of sediment size and stratigraphy must be responsible for differences in growth rate, height and shape of landforms such as palsas. In other terms, landform size and morphology must be linked to the growth process and the material into which it takes place; variations in these characteristics should reflect the complexities of regional geological and geomorphological conditions.

This paper presents interpretations of ice lens sequences through series of drill holes. In the region of Rivière Boniface in northern Québec (Fig. 1), palsas up to $6 \mathrm{~m}$ high coexist with one metre high peat plateaus in bogs and fens. Both types of features are very abundant; in fact, they are the most conspicuous periglacial landforms in the region. A shallow drilling program was undertaken in one representative site for each type of feature in order to 1) determine stratigraphy and internal structure, 2) find an explanation for the difference in shape and height.

\section{THE RIVIĖRE BONIFACE REGION}

The study area is located at the tree line, about $130 \mathrm{~km}$ SE of the community of Inukjuak, some $35 \mathrm{~km}$ inland from the eastern shore of Hudson bay. The long-term (1966-93) mean annual air temperature in Inukjuak is $-6.9^{\circ} \mathrm{C}$. The average for the coldest month (February) is $-25.5^{\circ} \mathrm{C}$; it is $9.2^{\circ} \mathrm{C}$ for the warmest month (July) (our compilation of Environment Canada's data). Records from an automatic meteo station $5 \mathrm{~km}$ 


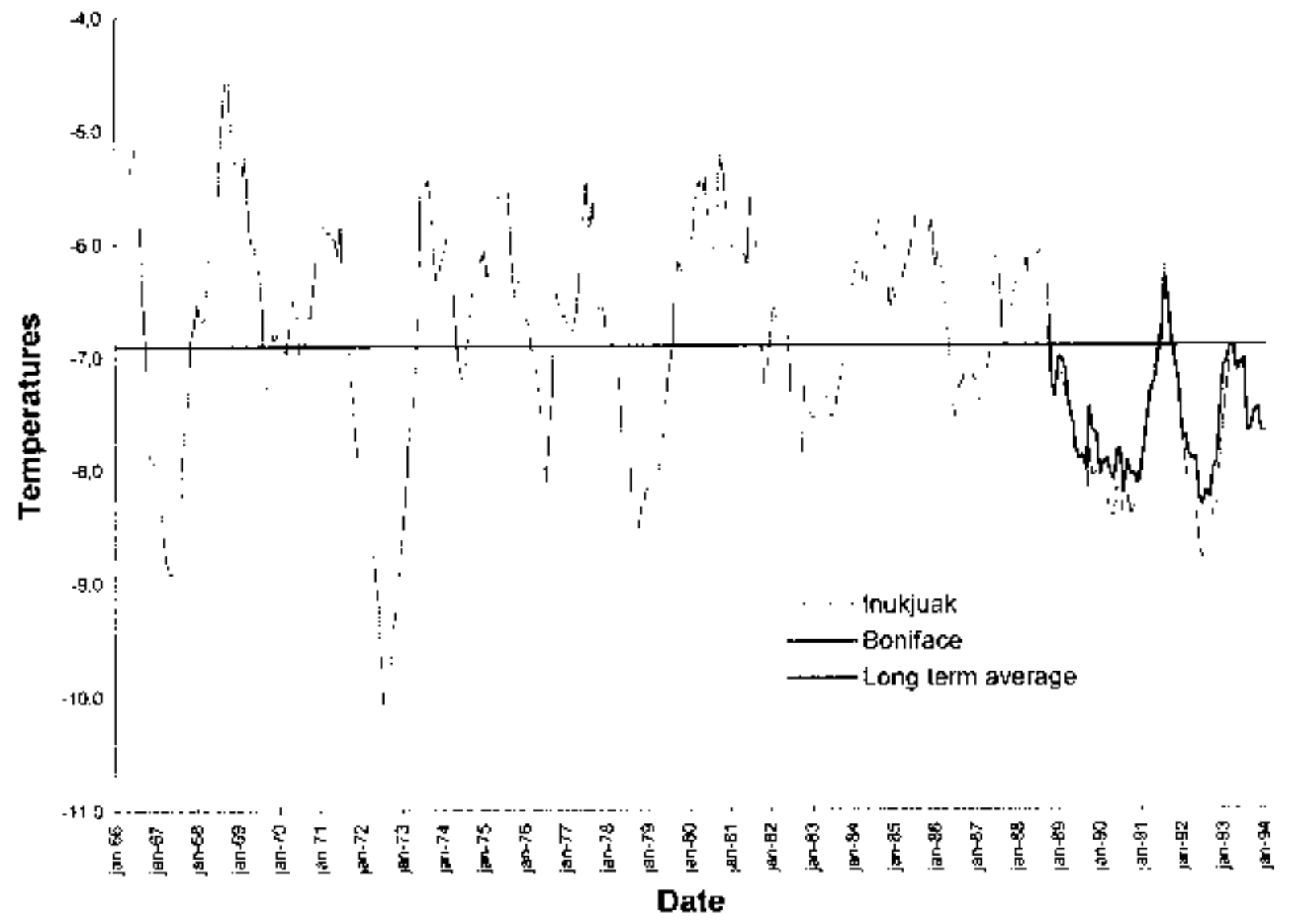

FIGURE 2. Mean annual air temperatures (12 months running averages) in Inukjuak (January 1966-December 1993) and at Rivière Boniface (January 1988-December 1993).

east from the study site, spanning from 1990 to 1995 , measured a mean annual air temperature of $-7.4^{\circ} \mathrm{C}$ (S. Payette, personal communication). Over the five years of overlapping data between this station and Inukjuak (1989-1993), the study region was about $0.2^{\circ} \mathrm{C}$ warmer on average per year. From 1966 until 1981, the mean annual air temperatures were rather stable despite yearly variations around the average; from 1981 to 1994, the temperatures were generally decreasing and they were below the long term average from 1988 to 1994 (Fig. 2). During that interval, the year 1992 was especially cold $\left(-8.3^{\circ} \mathrm{C}\right.$ at Rivière Boniface and $-8.8^{\circ} \mathrm{C}$ in Inukjuak), a wide-scale phenomenon observed in the Eastern Canadian Arctic and probably related to the impact of the eruption of Mount Pinatubo (Allard et al., 1995). Mean annual precipitation is about $400 \mathrm{~mm}$, of which about $35 \%$ consist of snow. The regional vegetation consists of a mosaic of black spruce stands in depressions and on hill slopes and open tundra on summits and plateaus. Repeated fires and a general climate deterioration over the last millennium have resulted in the abundance of Picea krummolhz (Arseneault and Payette, 1997).

The region has a peneplain relief developed on Archean granite-gneiss (Avramtchev, 1982). The topography is rolling with most hills having their summits around $200 \mathrm{~m}$ a.s.l. and
Températures moyennes annuelles de l'air (moyennes glissantes de 12 mois) à Inukjuak (janvier 1966-décembre 1993) et à la rivière Boniface (janvier 1988-décembre 1993).

valleys and lake basins having their bottoms around $110 \mathrm{~m}$ a.s.I. The region was deglaciated by 7000-6500 BP (Gray et al., 1993). Numerous drumlins trend E-W. Following deglaciation, the Tyrrell Sea inundated the land at elevations below $175 \mathrm{~m}$ leaving many rock and till hills protruding above the marine limit. Shells collected in postglacial marine silts at $140 \mathrm{~m}$ a.s.l. yielded an age of $5810 \pm 120$ (UL-1202) (Rousseau, 1996). Below the marine limit, numerous De Geer moraines mark former ice-frontal positions and gravelly raised beaches step the slopes of hills and drumlins. Most of those former shorelines do not have a clear geomorphic expression as fetches and wave energy were limited in an intricate pattern of shallow inlets and islands (Allard and Seguin, 1985). Fine marine sediments were deposited in the basins at lower elevations. Geophysical soundings have shown that the thickness of the marine clays in these basins can be as much as $85 \mathrm{~m}$ (Lévesque et al., 1988).

Palsas in the region are mostly circular in plan with diametres ranging from 40 to $60 \mathrm{~m}$ and heights from 4 to $6 \mathrm{~m}$. Very often, they occur in the deepest valleys and depressions. As most bedrock valleys are rather narrow, the palsas very often appear in beaded single lines, sometime along distance as great as $1 \mathrm{~km}$. The peat plateaus are scattered in the landscape and are generally found in wide open valleys between 
hills or between drumlins, several metres above the level of lakes and rivers.

\section{METHODS AND PRESENTATION OF RESULTS}

One palsa was selected in the centre of a series that grades into a plateau towards its eastern end (Rousseau, 1996). The fen surrounding the palsas is only 1-2 $\mathrm{m}$ above the level of the river. The site is about at $112 \mathrm{~m}$ elevation a.s.I. Two section lines (lines $T$ and $L$ ) were surveyed across the top of the palsa (Precision of $\pm 1 \mathrm{~cm}$ from benchmark at metre 0 of each line) (Fig. 3). Line T runs transversally to the palsa series, from unfrozen ground on the south side to unfrozen ground on the north side. Line $L$ runs $W-E$, parallel to the series, from near the top of the preceding palsa, across the intervening depression and to the somewhat lower plateau on the eastern side. The two sections intersect each other at metre 31 on each line, on the top of the palsa, $5.7 \mathrm{~m}$ above the surrounding fen. Hole 31 (labeled T31 and L31) is common to the two sections. Every two metres along the transverse section and every four metres along the longitudinal section, a pit was dug to the thaw front (early July) and from that depth a hole was drilled in the permafrost. Operated by two men, our portable drill has a single-walled, $5 \mathrm{~cm}$ diameter, corer with a ring bit made of carbide and diamonds. It cuts easily through mixtures of soil and ice; short core sections $25-40 \mathrm{~cm}$ long are recovered. Total core recovery was nearly $100 \%$ at all holes and the depths reached are 3-3.2 $\mathrm{m}$.

One peat plateau was selected some $12 \mathrm{~km}$ downstream from the palsa site, at an elevation of about $2 \mathrm{~m}$ above the river level (Fig. 4). Located in a wide, shallow depression between a drumlinoid ridge on the north side and a rock outcrop on the south side, the plateau is roughly square in plan. To the east, the plateau is bounded by a shallow pond; on the three other sides, it is bounded by fens. A 76 m long S-N section was surveyed across the plateau; the highest point along the profile at metre 70 is $1.3 \mathrm{~m}$ above the surrounding fen. Considering the relatively flat surface, only five holes were drilled along the profile (metres 4, 16, 44, 54, 72) with a spacing judged sufficient to represent all potential stratigraphic variations in this environment. For comparison purposes, one hole was also drilled just outside the plateau edge in the fen on the three sides not occupied by ponded water.

The pit sections and the cores were described and drawn to scale in the field. About one core section out of five was photographed from the 36 cores taken. The thickness of every ice lens was measured, except for the very thin ones which were just noted as $<1 \mathrm{~mm}$. As age estimates of the early and final peat accumulation were desired, samples were taken at basal stratigraphic contacts and near the surface for radiocarbon dating (Allard et al., 1986). To help interpret the mechanical evolution of the palsa, several other samples were taken on the cores for dating in order to detect potential chronological inversions and stratigraphic disturbances in the peat cover. The fine sediments in-between ice lenses were sampled down core; grain-size analyses with a

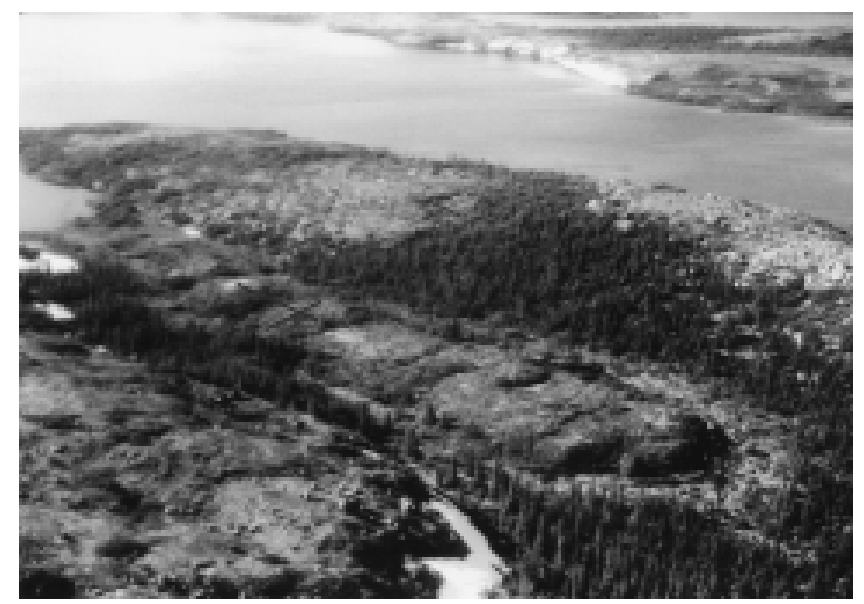

FIGURE 3. The studied palsa and surroundings. Location of transects of Figure 5.

La palse étudiée et son milieu. Localisation des profils de la Figure 5.

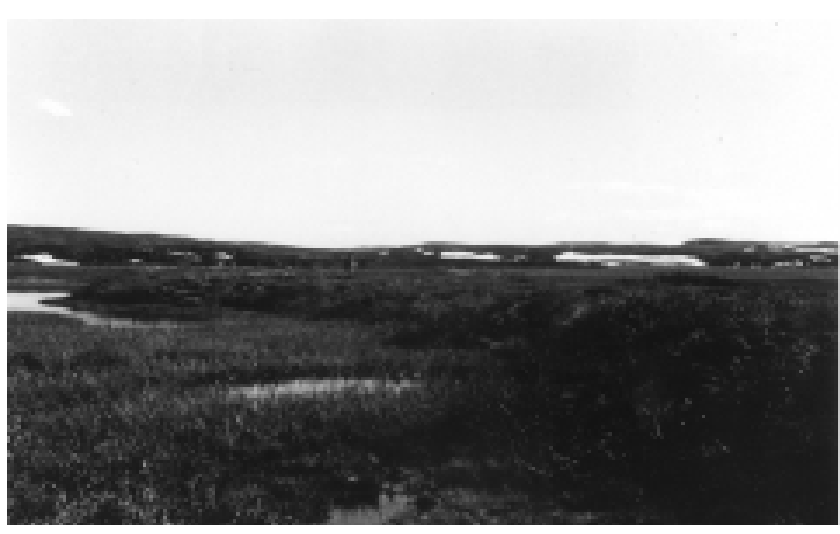

FIGURE 4. The peat plateau. A person in the centre provides a scale. Le plateau palsique. La personne au centre donne l'échelle.

on 18 samples from the peat plateau, making sure that a reasonable spatial and depth representation of samples was attained. The sand-silt and the silt-clay boundaries used thereafter are $63 \mu \mathrm{m}$ and $4 \mu \mathrm{m}$, respectively. The salt content of water extracted from the samples was measured with a hand-held refractometre. Since all the samples had $0 \%$ salinity, this factor potentially affecting ice-segregation can be discarded in this study.

Previous studies on palsas and like mounds have shown that mound height represents roughly $1 / 3$ the thickness of the permafrost contained in them (Evseev, 1973; Lévesque et al., 1988). In mounds of similar size and geomorphic setting in the region, permafrost thicknesses are about 19-21 m (Fortier et al., 1991). In order to better assess the geometry of the permafrost body under the palsa and to partially compensate for the absence of information in the deep core of the mound, a hole was drilled from the top using the waterjet method, with the water being pumped from a nearby pond. Although no core can be obtained with this technique, the presence of ice layers in the ground can be easily "felt" through repeated mechanical resistance to pipe penetration. 
Using all the available lengths of pipe, a depth of $17 \mathrm{~m}$ was reached, without breaking through permafrost base.

Core stratigraphy was drawn on topographic sections of the palsa and the peat plateau (Figs. 5 and 6) for interpretation. A decision had to be made as to the orientation of dipping ice-lenses as there was no technical mean to properly orient cores: they are represented as parallel to slope direction. The justification for this choice is that the dip direction of peat/sand, peat/silt and other stratigraphic contacts seen in pits also parallel the slope direction. Furthermore, dip direction can be argued on thermodynamic and mechanistic grounds (see below); still, it can not be excluded that, in several circumstances, ice-lens dip differs in direction with slope.

\section{INTERPRETATIONS}

\section{MORPHOLOGICAL-STRATIGRAPHIC RELATIONSHIPS IN THE PALSA}

The stratigraphy prior to palsa formation was evidently peat/sand/clayey silt, the same as the widespread regional stratigraphy observed in many studies in the Tyrrell Sea region and reflecting: shallowing of the sea, emergence and a local fluvial influence, followed by peat inception and growth (Lavoie and Payette, 1995; Allard and Seguin, $1985,1987)$. This original sequence is found in several drill holes where apparently little deformation has occurred during palsa growth, for instances in holes T18, T34, L5 and L47. In some holes, silt, sand, and even small gravel layers are interstratified in the peat where there is no evidence of deformation (e.g. T20, T34, T37, L20, L39, L43). It is probable that these mineral layers were laid by ephemeral creeks or occasional floodings of the fen prior to palsa formation. As the bedrock valley is narrow and the sides are steep, thick snowbanks accumulate on the steep slopes. It is to be expected that fast spring melts or heavy rains in the past sporadically flooded the fen and laid coarse mineral sediments eroded from till from the valley slopes. The inter-mound zone (holes L8 to L24) is an area of concentration of coarse sand and gravel in the peat; this sector of the fen either was the location of a small creek or was sporadically flooded by running water before permafrost formation.

The north slope of the palsa is significantly steeper than the south one, as seen on the transverse profile (Fig. 5B). This is a character also observed on the other palsas in the same field. On the summit, a circular patch about $5 \mathrm{~m}$ in diametre has no peat cover, and silty sand outcrops in several frost boils. The summit bears a very discontinuous low $(5-10 \mathrm{~cm})$ vegetation cover. Mid-slope, the vegetation is denser and shrubby, being dominated by $50-60 \mathrm{~cm}$ high Betula glandulosa. On the lower slopes, Picea mariana trees up to $2 \mathrm{~m}$ high suggest a more sheltered environment to wind and a deep snow cover. Based on the shape of spruce trees and the height of shrubs, an estimate of maximal snow depth was drawn on the profiles (Figs. 5 and 6). The thaw front in the first half of the summer is shallower on the northern slope where the peat cover is continuous. The steeper northern slope is a function of less solifluction, which results from: 1) the heat balance of the asymetric mound, as this side is closer to the core, 2) shallower thaw penetration in summer due to a continuous peat cover, 3) aspect away from the daily sunlight.

The shape of the palsa closely reflects the shape of its frozen silt core that has been thrust upwards by frost heave. In fact, the cover of sand and peat that extended over the silt surface prior to palsa formation was simply raised and redistributed on the slopes without contributing very much to the volume of the mound. This redistribution had the effect of generally smoothing the profiles by plastering the slopes and the inter-mound depression.

At the foot of both the southern and the northern sides, the frozen silt core plunges very steeply. Between the two successive palsas, the steeply dipping silt surface virtually implies that shear planes akin to a normal fault zone are present in the frozen mass. These "fault zones" produce the steep surface slopes between holes L5 and L8 and between L24 and L28. They must also have sheared the peat cover, as illustrated by the vertical sand-peat contact in hole L24. It is noticeable that the permafrost base was reached in hole L12 in the centre of the inter-mound hollow, the permafrost there being only $2.1 \mathrm{~m}$ thick. In hole T44, at the base of the north slope, the permafrost base was also reached $1.5 \mathrm{~m}$ deep in sand underneath the peat cover; the $2.3 \mathrm{~m}$ hole did not reach the silt core, confirming the steep plunge of the permafrost-unfrozen ground contact. The permafrost body under the palsa has almost vertical contacts with the surrounding unfrozen ground.

Along the transverse profile, the thickness of sand is greater at the base of the slopes than on the top. Two factors may account for this: 1) some slope sliding and gelifluction took place during the heaving of the palsa, delivering cover material (sand and peat) to the base of slopes, 2) surface erosion by slopewash (snowmelt water and rain), transporting sand from the top of the palsa after the peat cover was ruptured and mudboil activity started exposing and mixing bare mineral sediments (holes T28 and T31). In the pits on the slopes, gelifluction deformations were observed in the active layer, also suggesting that this process helped moving the sediments downwards. Most of the pure sand cover is now gone from the top of the palsa and the underlying silt comes very close to the surface (less than $1 \mathrm{~m}$ ). It is also quite possible that wind deflation in winter helped in eroding the original peat and sand cover from the snowfree palsa summit (Allard et al., 1986).

\section{RADIOCARBON DATING}

The oldest date obtained from peat in hole L24 (5740 BP, see Table I for laboratory references and $\sigma$ errors) is considered too old and unreliable. The amount of carbon remaining for scintillation counting after sample pre-treatments and synthesis of benzene was smaller than what is acceptable, a factor that tends to overage dates in addition to increasing the $\sigma$ error. Errors on the other dates are large because of the rather small masses of carbon in our samples; this result 

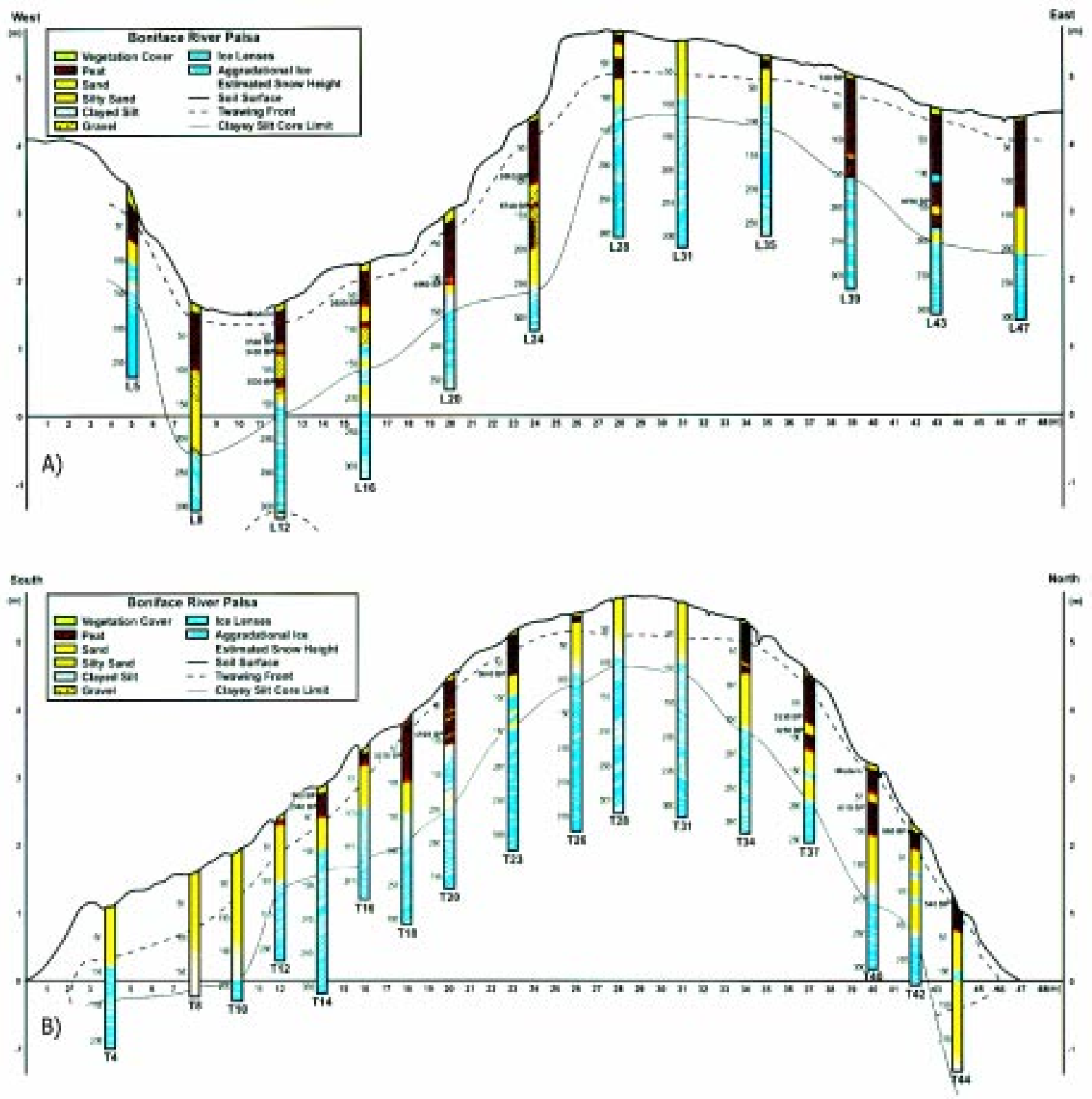

FIGURE 5. A) Longitudinal profile across the palsa. B) Transversal profile across the palsa.

from an overestimation of sample size in the field as a compromise was looked for between sample thickness and apparent peat content of frozen specimens. Three specimen yielded dates over $4000 \mathrm{BP}$ (L20, L43, T40); the basal age of $4920 \mathrm{BP}$ in hole T20 correlates very well with numerous basal forest peat dates in the tree line region east of Hudson Bay (Allard and Seguin, 1987; Lavoie and Payette, 1995). Organic accumulation thus begun by 4.9 ka BP. A thin organic cover had expanded over the area by $4.0 \mathrm{ka}$ and was slowly thickening.

Near surface peat just underneath the xeric vegetation cover ranges in age from 900 BP (T14) to "modern". Contamination of samples taken just below the living vegetation
A) Profil longitudinal de la palse. B) Profil transversal de la palse.

mat by rootlets cannot be completely ruled out (Allard et al., 1986), thus possibly explaining the "modern" ages. It can however be safely assessed from the number of dates in that range that peat growth in hydric conditions stopped sometime during the last few hundreds years, likely corresponding to inception of the palsa. This interpretation locates the beginning of palsa formation in a cold period well documented in the region by tree rings (1580 AD (or ca. $360 \mathrm{BP}$ ) to $1880 \mathrm{AD}$ ) (Stuiver and Pearson, 1993) and corresponding to the Little Ice Age (Arseneault and Payette, 1997).

Palsa growth certainly provoked the sliding of peat sheets. At some places on the slopes, the peat layer is thinner and has a younger basal age; for example, in hole T23, 


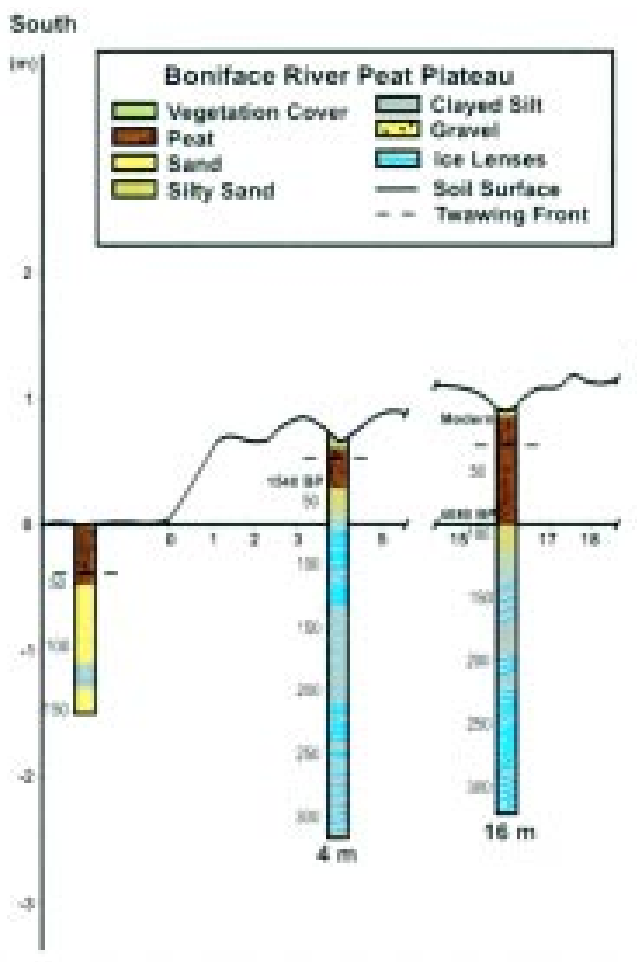

FIGURE 6. Profile across the peat plateau.

only $3 \mathrm{~m}$ away from T20, the basal peat age is only $3640 \mathrm{BP}$; in hole T14, the $2940 \mathrm{BP}$ date $30 \mathrm{~cm}$ deep suggests that the basal portion of the peat layer is missing. Also, some peat layers separated by sediment layers have age inversions, although in most cases the $\sigma$ errors overlap. These cases suggest that shearing parallel to the bedding took place with sheets of peat sliding a few metres downslope and covering pre-existing peat of similar age. Most mineral intervals in the peat layer are composed of frozen massive sand without sedimentary structures or evident shear planes; some are made of ice-deformed silt. It is difficult therefore to distinguish on a safe criteria between deformation events during palsa growth and sedimentary events during previous peat accumulation (see above). But, the dates, some high angle contacts, the discontinuous cover on slopes, and variations in thickness all clearly indicate that shearing and sliding did take place. The peat cover is now rather thin on slopes, particularly along the transverse profile. On the contrary, holes L39, L43 and L47, where little deformation seems to have taken place, have a peat thickness of about $1.5 \mathrm{~m}$, which could have been near the original maximum thickness before palsa inception. Although it is not certain that the peat cover was uniform over the site because of possible spatial variations in peat accumulation rate prior to palsa formation, the thin and discontinuous organic cover remaining on the mound strongly suggests that an important amount of peat has also been eroded away during growth and since.

\section{CRYOSTRATIGRAPHY AND SEDIMENTOLOGY}

The frozen peat and sand in the palsa contain only pore ice. The gravimetric water content from thawed sand sam-

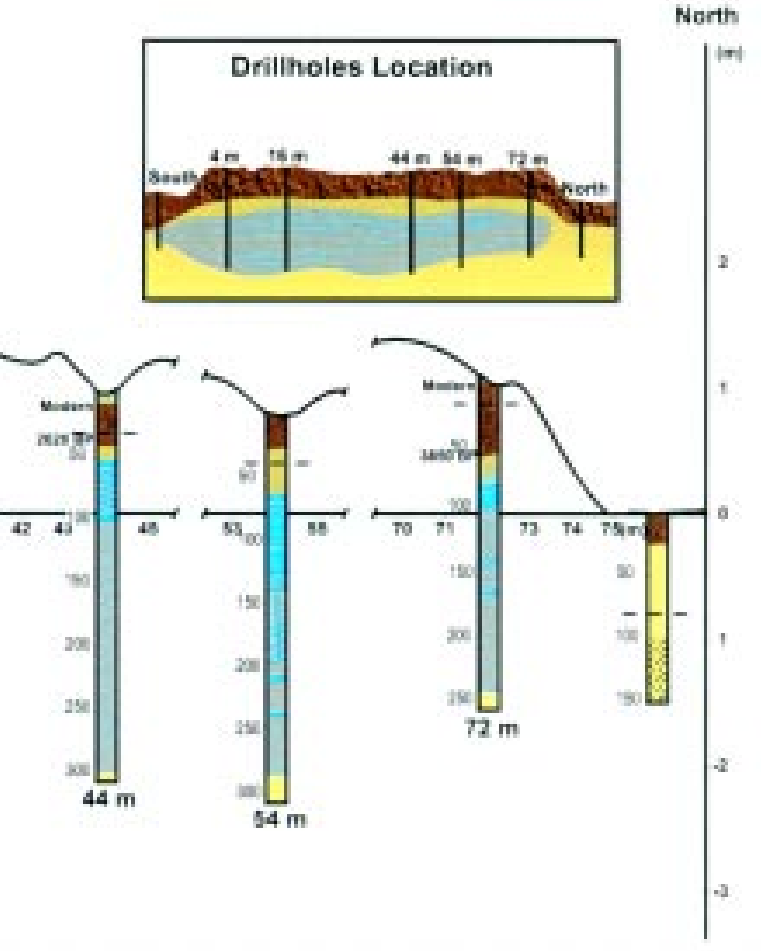

Profil à travers le plateau palsique.

ples was only $20-30 \%$, indicating non-saturated conditions. The situation in the clayey silt is much more complex. The average thickness of all the ice-lenses in the 28 cores is $11.3 \mathrm{~mm}$, numerous ones being up to $40 \mathrm{~mm}$ thick. Volumetric ice content, estimated visually, is often above $80 \%$, i.e. an equivalent of about $135 \%$ water content per dry weight (of course the volumetric value is $100 \%$ if ice lenses are considered individually). Figure 7A presents a summary of the grain-size distribution in the top 3 metres of the palsa. There is a trend of coarsening upward (Fig. 7B and 7C), probably a result of increasing agitation with shallowing water during emergence of the site. This grain-size gradient may have favored a gradual increase of ice lens thickness with depth (Fig. 8), through an increase downward in soil capillarity and hydraulic conductivity for feeding ice lens growth in the freezing fringe of the aggrading permafrost.

However, vertical changes in grain size distribution cannot explain some prominent features of ice lens sequences. In most holes, series of thicker lenses (i.e. $>10 \mathrm{~mm}$ ) begin to appear from depths of 1.5-1.6 m downwards. This may be interpreted as follows: during the first one or two winters of permafrost formation, the thermal gradient was steep in the soil, thus favoring fast freezing and not allowing the best conditions for ice lens segregation; over the following years, as the permafrost deepened, the gradient became lower thus favoring a slower penetration of the freezing front at the base of the aggrading permafrost, with a thicker freezing fringe and more time for ice segregation. Also, alternating series of thick and thinner ice lenses are found in the cores, in some cases at approximately corresponding depths. For instance, holes T20, T23, T26, T28, T31 and T34 have a 
TABLE

List of radiocarbon ages on peat from the palsa and the peat plateau

\begin{tabular}{|c|c|c|c|c|}
\hline \multicolumn{5}{|l|}{ Palsa } \\
\hline Hole no. & depth $(\mathrm{cm})$ & Lab. no. & Age & $\sigma$ \\
\hline$\overline{T 14}$ & $9-10$ & UL-1220 & 900 & 100 \\
\hline T14 & $27-30$ & UL-1208 & 2940 & 100 \\
\hline T18 & $53-59$ & UL-1332 & 3370 & 110 \\
\hline T20 & $91-100$ & UL-1237 & 4920 & 100 \\
\hline T23 & $60-64$ & UL-1210 & 3640 & 110 \\
\hline T37 & $68-113$ & UL-1327 & 3330 & 90 \\
\hline T37 & $91-95$ & UL-1211 & 3250 & 110 \\
\hline T40 & $11-35$ & UL-1221 & modern & - \\
\hline T40 & $62-83$ & UL-1213 & 4110 & 120 \\
\hline T42 & $6-12$ & UL-1330 & 860 & 110 \\
\hline T44 & $3-12$ & UL-1329 & 540 & 90 \\
\hline L12 & $6-10$ & UL-1226 & modern & - \\
\hline L12 & $55-60$ & UL-1214 & 3560 & 150 \\
\hline L12 & $67-75$ & UL-1215 & 3430 & 120 \\
\hline L12 & $109-124$ & UL-1216 & 3530 & 100 \\
\hline L16 & $50-63$ & UL-1217 & 2680 & 110 \\
\hline L20 & $102-108$ & UL-1218 & 4060 & 100 \\
\hline L24 & $92-96$ & UL-1326 & 3060 & 80 \\
\hline L24 & $127-131$ & UL-1328 & 5740 & 170 \\
\hline L39 & $5-10$ & UL-1225 & 740 & 100 \\
\hline L43 & $140-145$ & UL-1219 & 4090 & 90 \\
\hline \multicolumn{5}{|l|}{ Plateau } \\
\hline Hole no. & depth $(\mathrm{cm})$ & Lab. no. & Age & $\sigma$ \\
\hline $4 \mathrm{~m}$ & $30-36$ & UL-1181 & 1540 & 80 \\
\hline $16 \mathrm{~m}$ & $4-8$ & UL-1222 & modern & - \\
\hline $16 \mathrm{~m}$ & $86-90$ & UL-1259 & 4080 & 110 \\
\hline $44 m$ & $7-12$ & UL-1224 & modern & - \\
\hline $44 \mathrm{~m}$ & $40-44$ & UL-1179 & 2620 & 100 \\
\hline $72 \mathrm{~m}$ & $9-15$ & UL-1223 & modern & - \\
\hline $72 \mathrm{~m}$ & $46-51$ & UL-1252 & 3850 & 110 \\
\hline
\end{tabular}

series of generally thin lenses between 1.7 and $2.1 \mathrm{~m}$, a series of thick lenses from 2.1 to $2.35 \mathrm{~m}$, and, in T28, T31, and T34, another series of thinner lenses from 2.35 to $2.6 \mathrm{~m}$. Although less conspicuous, a similar observation can be made for holes L28, L35 and L39. The holes sharing this general stratigraphic sequence are all in the upper core of the palsa. Unfortunately, precise stratigraphic correlation between holes is not possible and no single lens can be traced from one hole to the next as ice segregation in the natural environment leads to wavy and discontinuous structures. Nevertheless, the observed serial alternations must have an explanation linked to the process of ice lens formation. For instances, time variations of thermal gradient could explain the pattern. In the first several years of palsa growth, the gradient was lower in years with milder winters (or thicker snowpack) or cooler summers, which would have favoured series of thick lenses; in years with colder winters (or thinner snowpack), the gradient was steeper and only thin lenses would have formed. Anyhow, the cause of such variations in ice lens thickness is likely to be linked to surface thermal variations.

A layer rich in aggradationnal ice and varying in thickness from $12 \mathrm{~cm}$ to $70 \mathrm{~cm}$ (in hole T16) was found at the top of permafrost in mineral sediments in ten holes (Fig. 5). This layers has a typical structure, being very ice-rich with soil clumps suspended in the ice (Fig. 9). A dual origin was proposed for such layers: 1 ) enrichment in ice from infiltration of water in summer, from the active layer into the upper permafrost along the reversed thermal gradient and, 2) upward migration of the permafrost table following surface sedimentation or climatic cooling (Burn, 1988; Shur, 1988; Cheng, 1983; Mackay, 1983). Recently, An and Allard (1995) modeled that such ice enrichment takes place in palsas that have a peat cover thinner than the active layer and in "mineral" or "cryogenic" mounds that have no peat cover. In the case here, all holes with aggradationnal ice have no peat or a peat cover thin enough so that the thaw front was already deeper in early July (Fig. 5). Percolation in the active layer (silt and sand) could therefore feed the formation of this ice. As erosion dominates over the top of the palsa, the observed apparent thinning of the active layer must be related to some recent cooling. Climate data indicate that the region got cooler indeed during the 13 years preceding the field work (Fig. 2).

\section{STRUCTURAL ELEMENTS}

Two striking features seldom reported from palsas (either "organic" or "mineral" ones) are high angle fractures (Fortier et al., 1992) and dipping ice lenses (Fig. 10). Some fractures have non-measurable displacements; others are faults with displacements up to several centimetres. The faults and the fracture planes contain ice "veins" of a thickness in the same order as the lenses they cross-cut (Fig. 5 and 10A).

Five processes could potentially generate dipping ice lenses and faults.

1) Heat flow geometry. If the $0{ }^{\circ} \mathrm{C}$ isotherm and the freezing front paralleled the topography of the mound during some stage of early growth, this would allow the establishment of an inclined freezing front near slopes; this could have occurred during some months or winters with a thinner than normal snow cover, in contrast to the typical situation when only the top of the mound is exposed because of wind deflation of the snow cover and differential accumulation on the sides. Thus, under typical conditions, the heat flux is vertical through the top of the palsa and the freezing front in the soil is horizontal; but variability in snow conditions (a potentially variable external factor) could occasionally change the geometry of heat flow.

2) Geometry of the stress field in the growing palsa. When ice lenses are growing along an horizontal freezing front in the palsa, the resistance to heave of the frozen overburden is less in the oblique direction, toward the sides of the mound; this could favor the formation of inclined lenses at an angle between the slope angle and the freezing front 

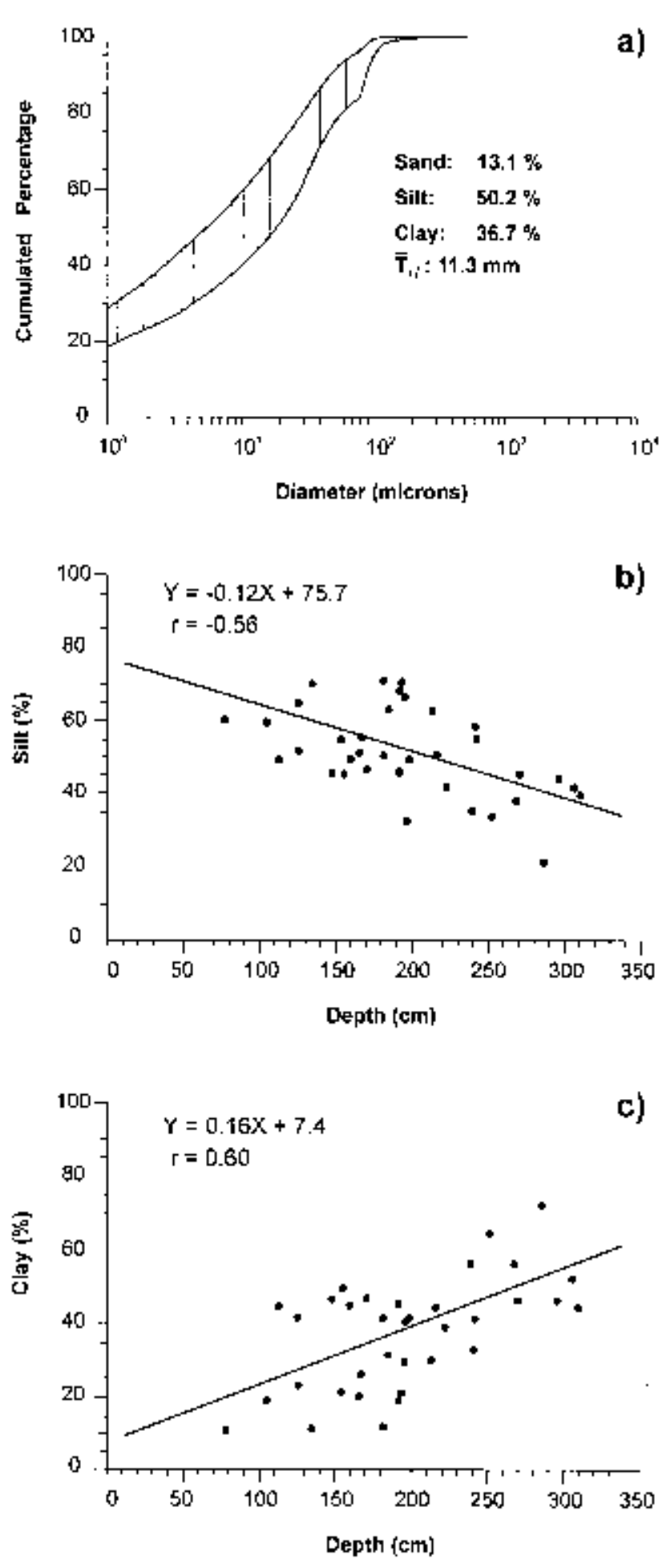

FIGURE 7. Grain-size parametres in the palsa. Upper-envelope curves and mean thickness of ice lenses. Middle- Silt content $v s$. depth. Lower- clay content vs. depth.

Caractéristiques granulométriques des sédiments de la palse. Hautcourbes enveloppes et épaisseur moyenne des lentilles de glace. Centre- le contenu en silt sur la profondeur. Bas- le contenu en argile sur la profondeur.

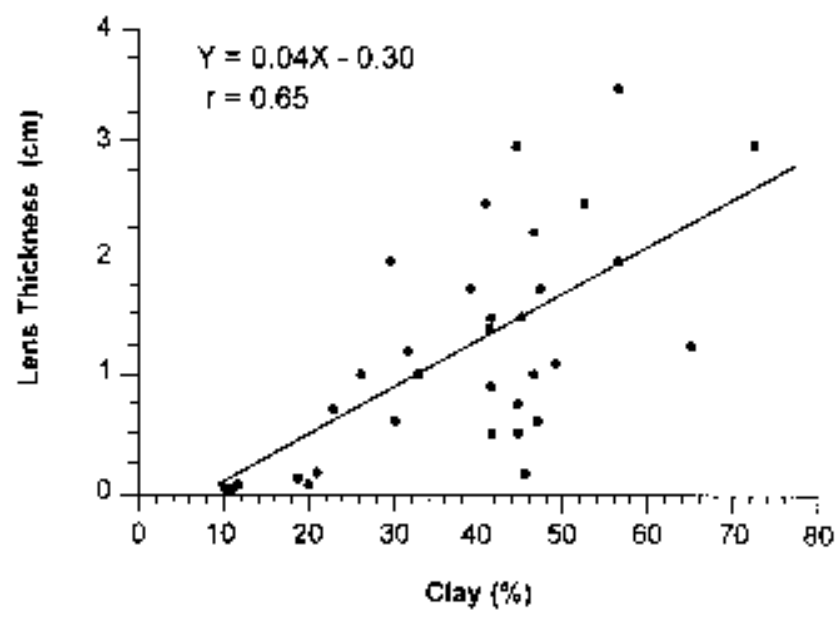

FIGURE 8. Ice lens thickness vs clay content in the palsa.

L'épaisseur des lentilles de glace sur le contenu en argile dans la palse.

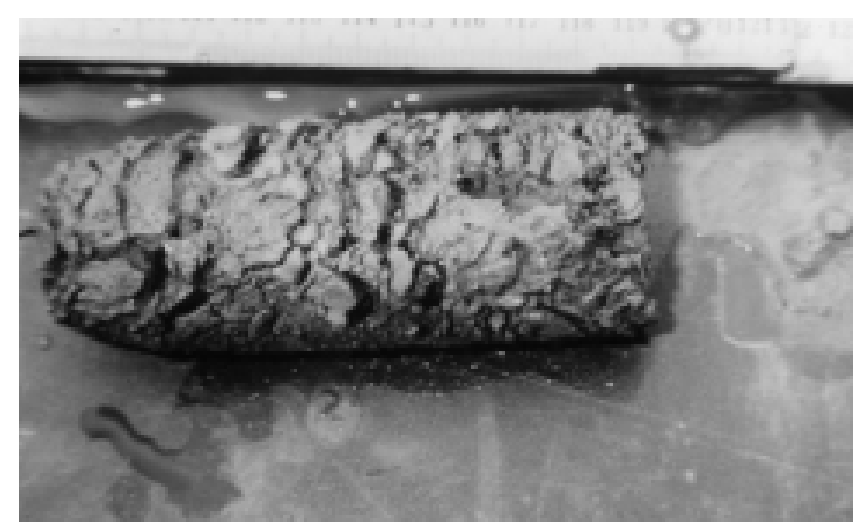

FIGURE 9. Aggradational ice near the top of permafrost in the palsa. Glace d'accroissement près du plafond du pergélisol dans la palse.

plane. Such a mechanical behavior was demonstrated in a real scale laboratory experiment around a chilled pipeline in Caen: some distance away (several decimetres) from the pipe, the ice lenses formed at an angle between the bulb freezing front around the pipe and the topographic surface of the soil in the cold room (Smith and Williams, 1990, 1995). It can also be argued that shearing of the lenses could take place in such conditions, giving way to the throw-dip relationship observed in the palsa.

3) Stratigraphic predispositions. Influence of stratigraphic contacts and sedimentary structures such as layering and rythmites (Pissart, 1987; Van Vliet-Lanoë, 1982, 1985). Since the sedimentary stratigraphy was horizontal, water flow for lens feeding would however have had to be active after doming of the original stratigraphy to produce sloping lenses, i.e. after the beginning of palsa growth. This potential explanation is difficult to accept in the present case because it implies the formation of major series of lenses in already deeply frozen soil behind the freezing front.

4) Thrustings from below. Faults can form as the permafrost expands at depth and the formation of new segregation ice deeper unevenly pushes the frozen overburden upwards 

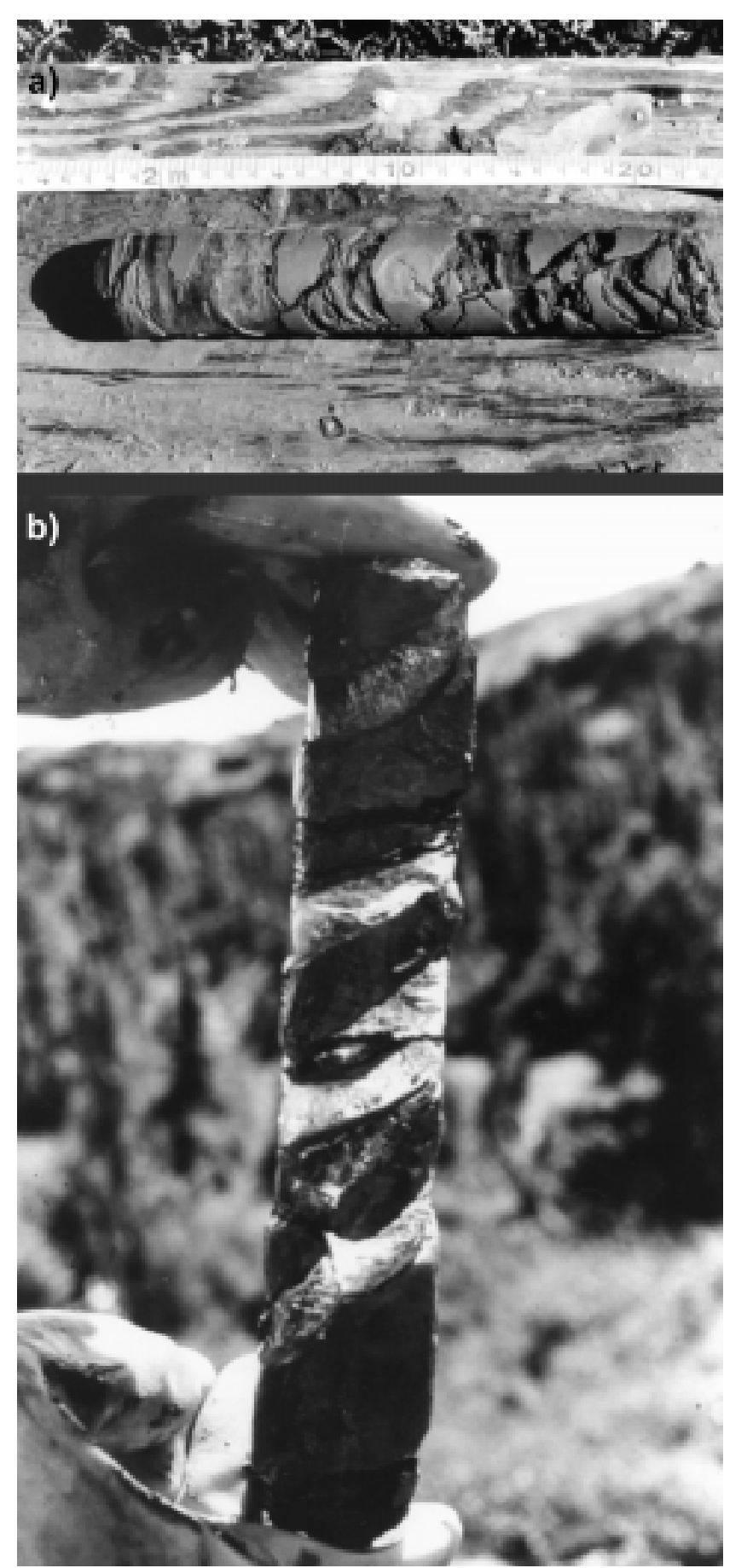

FIGURE 10. A) Faulted ice lenses in the palsa. B) Oblique ice lenses. A) Lentilles de glace faillées dans la palse. B) Lentilles de glace obliques.

(Fortier et al., 1992). Although apparently logical and straightforward at first, this mechanism can be considered as being only a partial cause explaining some, but not all, of the faults. But, in fact, such faulting does occur in permafrost: Savigny and Morgenstern (1986) observed slickensided surfaces of frozen soil along ice veins. No such surfaces were observed in our cores, but it cannot be ruled out that some exist, particularly deeper in the palsa.
5) Primary faulting during ice segregation. For instance, ice lens faulting often took place during the freezing of cores in Taber's laboratory experiments $(1929,1930)$, a fact that he explained by flaws in the continuity of water flow in the freezing fringe, due to irregularities in the fabric of his soil specimens. It is known that shrinkage cracks can also be generated in the soil immediately below a forming ice lens due to dessiccation and sediment consolidation in the cryosuccion processes. Konrad and Seto (1994) observed such vertical cracking in laboratory freezing of cores of undisturbed Champlain Sea clay, a material almost identical to the Tyrrell Sea clay. When a first lens is broken by a crack in the course of its formation, the crack plane continues to propagate downward for some distance with the freezing front, affecting the subsequent lenses, and migration of water can fill the crack to form an ice vein. In cases such as observed in the drilled cores, it would be difficult to explain complete ice filling of many fracture planes in already frozen ground by infiltration of liquid water through the permafrost. Vapor diffusion along cracks is another possible mechanism for water transport, but it usually leaves some open cavities in the ice and hoar ice has a different, characteristic, crystalline fabric, not seen in the cores.

\section{MORPHOLOGICAL-STRATIGRAPHIC RELATIONSHIPS IN THE PEAT PLATEAU}

The peat plateau has a micro-relief of $30-50 \mathrm{~cm}$ with alternating wet hollows and turf hummocks. Depressions have a Sphagnum dominated, saturated vegetation and organic cover. Ericacae dominate on hummocks, Betula glandulosa is widespread and several krummholz of Picea mariana are scattered over the surface. The average height of plants is about $20-40 \mathrm{~cm}$, which suggests a winter snow cover of equivalent thickness.

The peat cover is continuous but uneven, varying in thickness from 30 to $80 \mathrm{~cm}$. Throughout the plateau area, the peat rests on sand, via an abrupt stratigraphic contact. Then the sequence fines downward, from sand, through silty sand, to silt over a depth of $15-25 \mathrm{~cm}$. Series of ice lenses begin as the soil gets silty.

In three of the five holes ( $m$ 44, $m 54$ and $m$ 72), the base of the ice-rich clayey unit was met. The thickness of this unit is about $2.2 \mathrm{~m}$. The geomorphological context of the plateau (wide shallow depression, nearby rock outcrops) clearly suggests that the clay lens is of limited thickness also beneath the two other holes along the transect line as well as underneath the plateau in general. Beneath the clayey layer, a frozen sand and gravel (containing pebble and cobble size clasts) unit was encountered (Fig. 11). The three holes outside the plateau limits had no significant silt layers and only a thin frozen layer at the time of drilling that very probably thawed later in the summer.

As only pore ice formed in the frozen peat and in the upper and lower sand layers, the total height of the plateau is explained by ice lens formation in the clayey bed that underlies the plateau area. Some levels in this layer have volumetric ice contents of $80 \%$ (visual estimates); however 


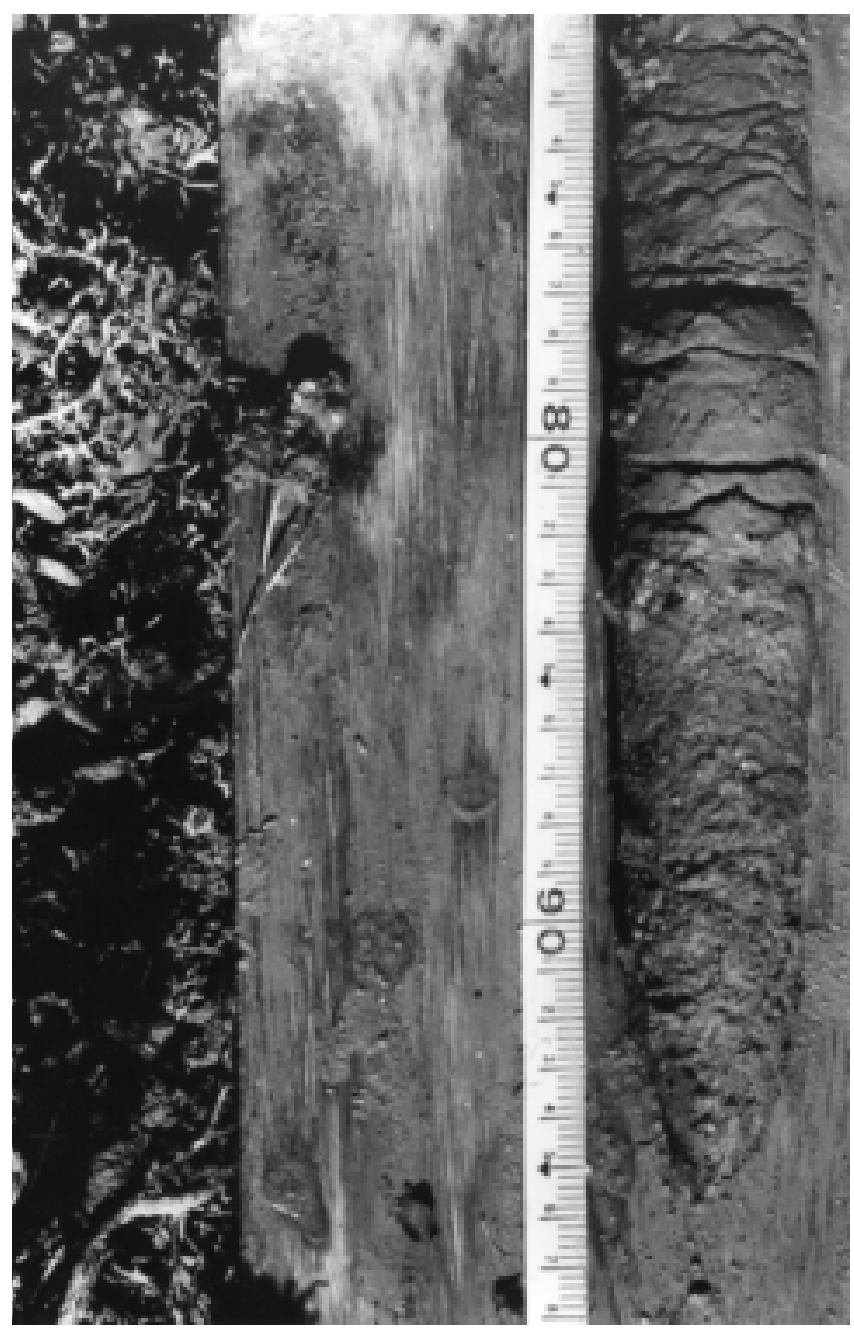

FIGURE 11. Stratigraphic contact between lensed clay and sand at the base of a core in the plateau.

Contact stratigraphique entre l'argile et les lentilles et le sable à la base d'une carotte dans le plateau.

other levels are poorer and an average value of $40 \%$ can be assessed. Therefore, the peat plateau was formed by the even heave of an underlying bed of clay that had an original thickness of about 1.3-1.4 m only.

\section{RADIOCARBON DATING}

As no deformations are apparent in the peat cover by any fault or inclined layer, it is very likely that the basal dates reflect the beginning of organic accumulation. The oldest one, $4080 \mathrm{BP}$, indicates that peat inception in this area was contemporaneous with early peat accumulation in the palsa area. However the peat cover in the open topographic depression apparently evolved from patches of organic soil that were initiated at different times and eventually merged altogether. All summit dates are "modern"; this can be due to the difficulty of separating living biomass and dead organic matter just below the surface since there is no real sharp contrast from a humid environment to a dry one.

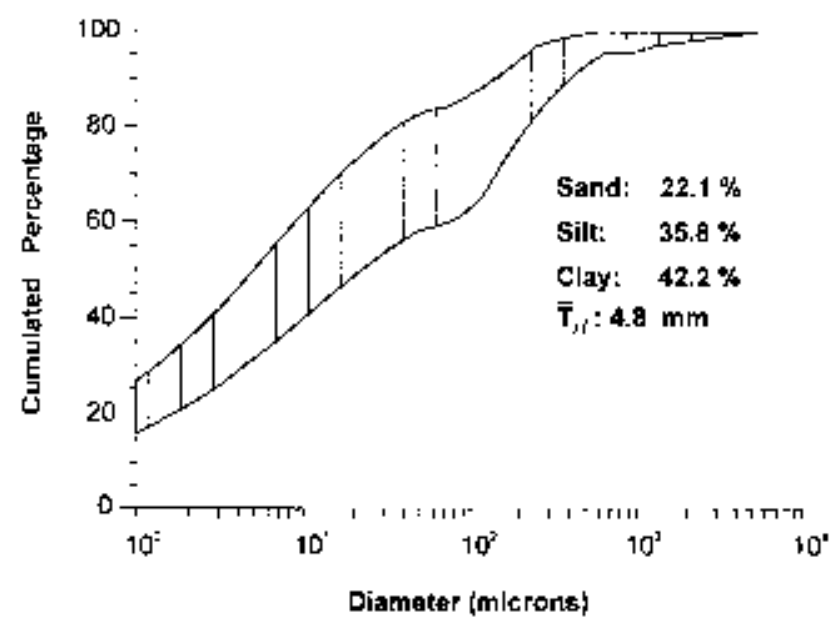

FIGURE 12. Envelope grain-size curves for the plateau, with mean icelens thickness.

Courbes granulométriques enveloppes du plateau, avec l'épaisseur moyenne des lentilles de glace.

\section{CRYOSTRATIGRAPHY, SEDIMENTOLOGY AND STRUCTURE}

Some rather thick ice lenses (up to $50 \mathrm{~mm}$ ) formed just at the sand-clay transition as seen in four cores out of five ( $\mathrm{m}$ $4, \mathrm{~m} \mathrm{44}, \mathrm{m} \mathrm{54}$, and $\mathrm{m} \mathrm{72})$. This is shallow $(50-70 \mathrm{~cm})$ and this vertical transition itself, where an abrupt change of thermal diffusivity takes place, probably coincides with the top of permafrost. In the hole at $\mathrm{m} 16$, the permafrost table must be within the locally thicker peat cover.

The average thickness of the ice lenses in the plateau is only $4.8 \mathrm{~mm}$, i.e. 2.4 times thinner than in the palsa. A difference in grain-size distribution of the sediments is the probable factor: the plateau has about $36 \%$ silt and $22 \%$ sand (Fig. 12) whereas the palsa has $50 \%$ silt and only $13 \%$ sand. The sandy-silty clay of the plateau is less frost-sensitive than the clayey silt of the palsa. A few vertical faults were also found in the peat plateau.

\section{DISCUSSION}

\section{A COMMON MODE OF FORMATION FOR THE PALSA AND THE PEAT PLATEAU}

Both the palsa and the plateau were heaved by the growth of ice lenses in a frost-sensitive silty or clayey sediment underlying the peat. The differences in height and in shapes between the two landform types are due simply to different thickness and extent of the underlying frost-sensitive sediment body or layer. The Tyrrell Sea clayey silt below the palsa is more than $17 \mathrm{~m}$ thick (Fig. 13A and B). The surrounding terrain in the valley bottom where it lies is not frozen and is saturated. In fact, most of the sediment mass in which ice lenses formed is below the level of the nearby lake (a widening of the river) and below the ground water level in the fen (Fig. 3). As the permafrost aggraded and penetrated deeper and deeper during the growth of the palsa, water was 

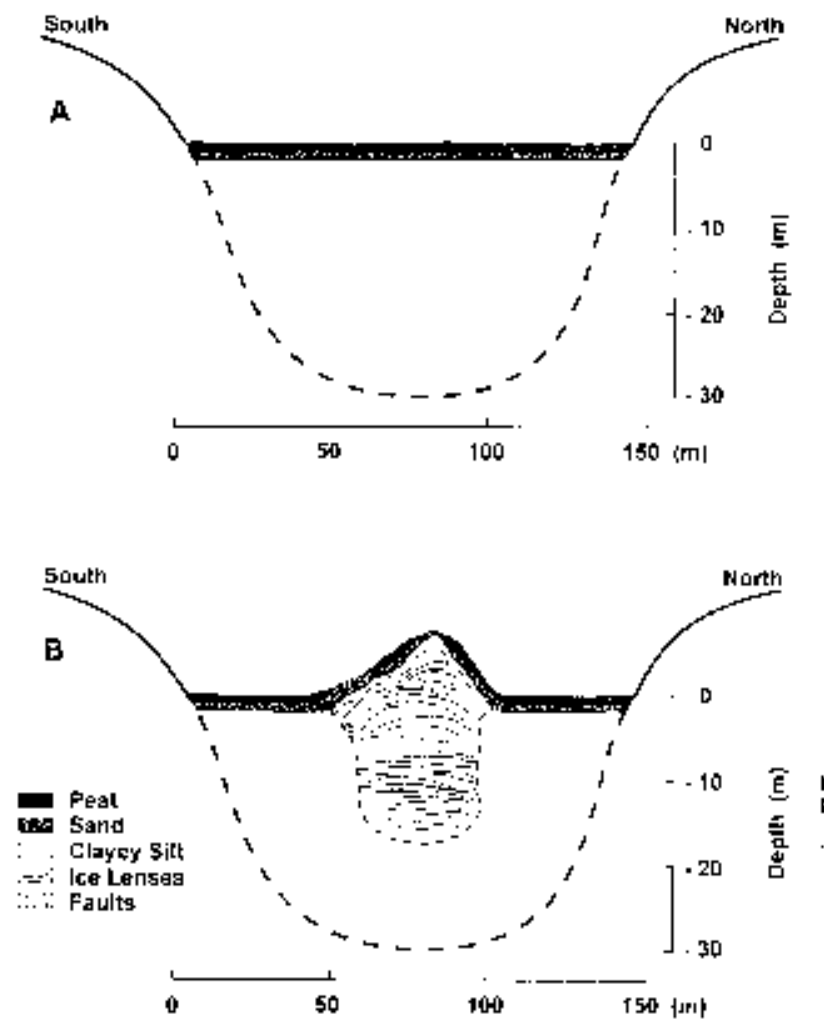

FIGURE 13. A) Setting of the palsa site before palsa formation. B) Actual setting of the palsa site. C) Setting of the plateau site before formation of the peat plateau. D) Actual setting of the peat plateau.

readily available for cryosuction and for feeding ice lens formation, thus leading to ice contents greater than what pore water alone would have permitted. No network of taliks is required to bring the water necessary for palsa formation (Worsley et al., 1995). In the case of palsas similar to the studied one, the thermodynamics of the system is the self limiting factor for permafrost expansion at depth and subsequent landform heave. As the permafrost gets deeper and deeper, the overburden pressure lowers the ice segregation temperature (about $-0.2^{\circ} \mathrm{C}$ at $20 \mathrm{~m}$ ) in the freezing fringe; as the thermal gradient near permafrost base becomes very low and new heat is brought in by the incoming water, not enough heat is dissipated upwards in the permafrost to allow the formation of new ice lenses; the system reaches a near steady state and, practically, heave stops (or nearly stops as the heat balance at the surface that sets the thermal gradient is never really stable) (An and Allard, 1995).

The peat plateau is also surrounded by unfrozen, saturated, terrain. However, it is underlain only by a thin layer of sandy-silty clay of limited spatial extent (Fig. 13C and D). When the permafrost penetrated in the coarse, non-frostsensitive sediment underneath (probably sandy till), heaved stopped.

Different frost sensitivities between soils at the two sites also affected the relative amount of heave: the higher sand content, with a lesser fraction of silt, resulted in generally
A) Contexte avant la formation de la palse. B) Contexte actuel de la palse. C) Contexte du plateau avant sa formation. D) Le plateau actuel.

much thinner ice lenses in the plateau. Would the thickness of the clayey layer have been "infinite" as in the case of the palsa, the elevation of the peat plateau would still have been much lower than the palsa. In fact, if we consider the ratio of mean ice lens thickness in the two sites as equivalent to a heave ratio, $(4.8 \mathrm{~mm} / 11.3 \mathrm{~mm}=0.42)$, the plateau would have been only about $2.4 \mathrm{~m}$ high (height of palsa, $5.7 \mathrm{~m} \mathrm{x}$ $0.42)$. Inside each landform type, vertical variations of grain size inherited from initial deposition very likely affected the growth and thickness of ice lenses in addition to variations in thermal gradients.

These observations generally concur with several others in the literature. For instance the importance of a silty material for the heave of both peat-covered and non- peat-covered ice segregation mounds was stressed in northern Scandinavia by Åhman $(1976,1977)$. All reports from drillings or geophysics in palsas and like landforms indicate the presence of mineral sediments with a degree of frost sensitivity and containing ice lenses (e.g. Gahé et al., 1987; Lagerbäck and Rodhe, 1986; Åkerman and Malmstrom, 1986; Sone and Takahashi, 1993; Spolanskaya and Evseyev, 1973).

The studied palsa, as most if not all the other ones in the region, formed in a deep rocky valley that was a local marine basin into which fine sediments accumulated. The plateau formed in a wide, shallow, depression that was a small bay along a former shoreline. The sediment is rather a tidal mud 
that was deposited in an environment affected by currents, waves and sea-ice, hence its higher sand content and wider grain-size distribution.

\section{INTERNAL STRUCTURE AND GEOMETRY OF GROWTH}

Despite some potential geometrical variations due to the gradually increasing size of the palsa and variable snow cover conditions through years, the principal direction of heat flow within a growing palsa or plateau is vertically upwards, thus setting the dominantly horizontal structure of the ice lenses. This leads also to steep sides around the edge of the heaved landforms with subsequent slope processes. This also implies that the silt and ice layers have to be fractured and faulted in order to accommodate for the deformation, principally between freezing and non-freezing terrain but also between faster and slower heaving parts of the landform.

The observation of numerous ice-filled fault planes of limited length in cores suggests that this vertical shearing takes place progressively, as heave takes place and the freezing front progresses downward, at the pace of palsa (or plateau) growth, resulting in the sum of all fault displacements to contribute to landform height. In general, the ice lenses tend to get thicker with depth but variations in thermal regime during permafrost aggradation may cause series of thinner or thicker lenses to alternate.

\section{THE ROLE AND FATE OF PEAT: THE "PALSA CYCLE"}

The peat cover slid on the slopes of the growing palsa, thinning on the sides and eroding on the top. Removal of the peat cover did not initiate degradation because, very likely, the top of the mound protrudes high enough above the surrounding snow cover and is exposed to sufficiently cold conditions. On the contrary, aggradational ice formed at the active layer/ permafrost contact under the mineral outcrop on top of the palsa, thus making a small contribution to heave and to the maintenance of the rounded shape of the mound. The proposed "palsa cycle" (Seppälä, 1986, 1988) therefore is not a universally applicable geomorphological concept. In each case, it must be superseded by standard thermal considerations. Furthermore, as a general fact, the presence of a peat layer is evidently not essential for the maintenance of permafrost in a cold region such as the Rivière Boniface area $\left(\right.$ MAT $\left.=-7^{\circ} \mathrm{C}\right)$. Hundreds of non-peat-covered mounds are also found in the study area and south of it, in the Lac Guillaume-Delisle region (Lévesque et al., 1988; Lagarec, 1982).

\section{DIFFERENTIAL HEAVE OR BREAKDOWN OF A HIGH PEAT PLATEAU?}

The studied palsa belongs to a complex which, viewed from the air, has the appearance of a high peat plateau that had been dissected into six or seven smaller entities along a series of transverse lineaments or fractures (Fig. 3), a pattern and a process commented upon in many other cases in northern Québec (e.g. Laberge and Payette, 1995; Lagarec, 1980). The "intermound" depression along our longitudinal transect shows no sign of an original fracture or ice wedge along which degradation could have been initiated, although it could have been missed between two holes. The relatively large amount of sand and gravel in the peat suggests that water flowed in this sector of the fen prior to palsa inception. If there was indeed a shallow creek or a wetter zone, then more snow must have accumulated in its slight depression and as the palsas on both sides heaved sooner and faster, the depression kept receiving relatively more snow. Even if the whole sector heaved as a vaster plateau, a linear depression must have existed continuously at this location. It can therefore be considered possible that: 1) the "intermound depression" never heaved higher than its present height; in this case sliding peat during growth of the palsas on both sides would have accumulated there, 2) the depression was heaved higher, but a furrow was always present at that location; then melting from below, i.e. from the base of permafrost would have provoked subsidence, followed by sliding of the peat from both slopes. A small pond lies near the depression on the north side of the palsa; some heat carrying water flow underneath the thinner permafrost could have induced basal melting. This question remains unsolved, but the horizontal structure of ice lenses and faults in the depressed zone, combined with the probable dynamics of ice segregation and heave, does not support evidently the collapse hypothesis.

\section{CONCLUSION}

The primary cause for the differences in shape and size between the palsa and the peat plateau are the different thicknesses and frost sensitivities of the sediment layers underlying the peat. The role of faulting during ice segregation appears as an important factor of differential heave during the growth of the palsa. Such a role needs to be verified in other geological contexts.

Supported by an understanding of the physics of permafrost growth, the structural analysis of ice lenses and deformations in permafrost can yield new detailed information on the origin of landforms such as palsas and related features. In return, such new knowledge has the potential to inspire new mathematical modelling approaches.

In the Rivière Boniface region, and very likely in similar northern Québec landscapes, the variability in shapes and sizes of ice segregation landforms is closely related to local Quaternary geological conditions, themselves the result of local landscape history. Considering the universal applicability of the ice segregation process, it is likely that a large amount of morphological variability attributed in the past to various factors such as peatland evolution, climate history, plant ecology, and geomorphological cycles, can in fact be accounted for by spatial variations in local superficial geology that react under given, more or less favorable, thermal regimes.

\section{ACKNOWLEDGMENTS}

The authors thank Dr. Baolai Wang who provided strong intellectual and physical support during the fieldwork. We thank also Dr. Serge Payette and his field party of 1994 for their friendly reception at their field camp and for occasionnal help during the drilling operations. Mr. Alain Cloutier 
drafted the figures. The project was supported by the Northern Scientific Training Program of the Department of Indian Affairs and Northern Development (Rousseau), a post-graduate scolarship from the Natural Science and Engineering Research Council of Canada (NSERC) (Rousseau), a NSERC research grant (Allard) and a grant from Fonds pour la formation de chercheurs et l'aide à la recherche du ministère de l'Éducation du Québec (Allard et al.). A preliminary version of the manuscript was improved thanks to the help of Dr. Linda Halsey. We are also indebted to Dr. Kenneth M. Hinkel and Dr. Matti Seppälä, the two journal reviewers, for their helpful comments and questions.

\section{REFERENCES}

A.C.G.R. (Associate Committee on Geotechnical Research), 1988. Glossary of permafrost and related ground-ice terms. National Research Council of Canada, Ottawa, Permafrost Subcommittee, Technical memorandum 142, $156 \mathrm{p}$.

Åhman, R., 1976. The structure and morphology of minerogenic palsas in northern Norway. Biuletyn Peryglacjalny, 26: 25-31.

1977. Palsar i Nordnorge. Meddelanden Fran Lunds Universitets, Geographiska Institution, Avhandlingar, 78, 165 p. (in Swedish with abstract in English, p. 137-151).

Åkerman, H. J. and Malström, B., 1986. Permafrost mounds in the Abisko area, northern Sweden. Geografiska Annaler, 68A: 155-165.

Allard, M. and Seguin, M.K., 1985. La déglaciation d'une partie du versant hudsonien québécois: bassins des rivières Nastapoca, Sheldrake et à l'Eau Claire. Géographie physique et Quaternaire, 39: 13-24.

1987. The Holocene evolution of permafrost near the tree-line, on the eastern coast of Hudson Bay (northern Québec). Canadian Journal of Earth Sciences, 24: 2206-2222.

Allard, M., Seguin, M.K. and Lévesque, R., 1986. Palsas and mineral permafrost mounds in northern Québec, p. 285-309. In V. Gardiner, ed., International Geomorphology, Part II, London, John Wiley.

Allard, M., Caron, S. and Bégin, Y., 1996. Climatic and ecological controls on ice segregation and thermokarst: The case study of a permafrost plateau in northern Québec. Permafrost and Periglacial Processes, 7: 207-228.

Allard, M., Wang, B. and Pilon, J.A., 1995. Recent cooling along the southern shore of Hudson Strait, Quebec, Canada, documented from permafrost temperature measurements. Arctic and Alpine Research, 27: 157-166.

An, W. and Allard, M., 1995. A mathematical approach to modelling palsa formation: Insights on processes and growth conditions. Cold Regions Science and Technology, 23: 231-244.

Arseneault, D. and Payette, S., 1997. Landscape change following deforestation at the Arctic tree line in Québec, Canada. Ecology, 78: 693-706.

Avramtchev, L., 1982. Catalogue des gîtes minéraux du Québec, Région de la baie d'Hudson, Québec. Ministère de l'Énergie et des Ressources, Service de la géoinformation, DVP-926, 13 p., color map at 1:125 000.

Burn, C.R., 1988. The development of near-surface ground-ice during the Holocene at sites near Mayo, Yukon Territory, Canada. Journal of Quaternary Science, 3: 31-38.

Cheng, G., 1983. The mechanism of repeated-segregation for the formation of thick layered ground ice. Cold Regions Science and Technology, 8: 57-66.

Dionne, J.-C., 1978. Formes et phénomènes périglaciaires en Jamésie, Québec subarctique. Géographie physique et Quaternaire, 32: 187-247.

- 1984. Palses et limite méridionale du pergélisol dans l'hémisphère nord: le cas de Blanc-Sablon, Québec. Géographie physique et Quaternaire, 38: 165-184.

Evseev, V.P., 1973. Migrational frost mounds, p. 121-123. In U.S.S.R. Contribution, Permafrost, Second International Conference, National Academy of Sciences.
Fortier, R., Allard, M., Lévesque, R. and Seguin, M.K., 1991. Caractérisation du pergélisol de buttes cryogènes à l'aide de diagraphies électriques au Nunavik, Québec. Permafrost and Periglacial Processes, 2: 79-93.

Fortier, R., Allard, M. and Seguin, M.K., 1992. Les cryofacies dans les buttes cryogènes limoneuses à Umiujuaq, Nunavik. Musk-Ox, 39: 67-79.

Gahé, É., Allard, M. and Seguin, M.K., 1987. Géophysique et dynamique holocène de plateaux palsiques à Kangiqsualujjuaq, Québec nordique. Géographie physique et Quaternaire, 41: 33-46.

Gilpin, R.R., 1980. A model for the prediction of ice lensing and frost heave in soils. Water Resources Research, 16: 918-930.

Gray, J.T., Lauriol, B., Bruneau, D. and Ricard, J., 1993. Postglacial emergence of Ungava Peninsula, and its relationship to glacial history. Canadian Journal of Earth Sciences, 30: 1676-1696.

Harris, S.A., 1993. Palsa-like mounds developed in a mineral substrate, Fox Lake, YukonTerritory. Proceedings, Sixth International Permafrost Conference, Beijing, China, 1: 238-243.

Konrad, J.M., 1994. Sixteenth Canadian Geotechnical Colloquium. Frost heave in soils: Concepts and engineering. Canadian Geotechnical Journal, 31: 223-245.

Konrad, J.M. and Seto, J.T.C., 1994. Frost heave characteristics of undisturbed sensitive Champlain Sea clay. Canadian Geotechnical Journal, 31: 285-298.

Laberge, M.-J. and Payette, S., 1995. Long-term monitoring of permafrost change in a palsa peatland in northern Québec, Canada: 1983-1993. Arctic and Alpine Research, 27: 167-171.

Lagarec, D., 1980. Étude géomorphologique de palses et autres buttes cryogènes en Hudsonie (Nouveau-Québec). Ph. D. thesis, Université Laval, Département de géographie, $308 \mathrm{p}$.

1982. Cryogenic mounds as indicators of permafrost conditions, northern Québec, p. 43-48. In Proceedings of the Fourth Canadian Permafrost Conference, Roger Brown Memorial Volume.

Lagerbäck, R. and Rhode, L., 1986. Pingos and palsas in northermost Sweden -Preliminary notes on recent investigations. Geografiska Annaler, 68A: 149-154.

Laprise, D. and Payette, S., 1988. Évolution récente d'une tourbière à palses (Québec subarctique): analyse cartographique et dendrochronologique. Canadian Journal of Botany, 66: 2217-2227.

Lavoie, C. and Payette, S., 1995. Analyse macrofossile d'une palse subarctique (Québec nordique). Canadian Journal of Botany, 73: 527-537.

Lévesque, R., Allard, M. and Seguin, M.K., 1988. Regional factors of permafrost distribution and thickness, Hudson Bay coast, Québec, Canada, p. 199-204. In Proceedings, Fifth International Permafrost Conference, Trondheim.

Mackay, J.R., 1983. Downward water movement into frozen ground, western Arctic coast, Canada. Canadian Journal of Earth Sciences, 20: 120-134.

National Wetlands Working Group, 1988. Wetlands of Canada. Ecological Land Classification Series, No. 24. Sustainable Development Branch, Environment Canada, Ottawa, Ontario and Polyscience Publications Inc., Montréal, Québec, $452 \mathrm{p}$.

Outcalt, S. I. and Nelson, F., 1984a. Computer simulation of buoyancy and snow-cover effects in palsa dynamics. Arctic and Alpine Research, 16: 259-263.

1984b. Growth mechanisms in aggradation palsas. Zeitschrift für Gletscherkunde und Glazialgeologie, 20: 65-78.

Pissart, A., 1983. Pingos et palses: un essai de synthèse des connaissances actuelles, p. 48-69. In H. Poser and E. Schunke, eds., Mesoformen des reliefs im Heutingen periglazialraum. Göttingen. Mathematisch, Physikalische Klasse, Dritte folge, $\mathrm{nr} .35$.

1987. Géomorphologie périglaciaire: texte des leçons de la Chaire franco-belge. Laboratoire de géomorphologie et de géologie du Quaternaire, Université de Liège, $135 \mathrm{p}$.

Pissart, A. and Gangloff, P., 1984. Les palses minérales et organiques de la vallée de l'Aveneau, près de Kuujjuaq, Québec subarctique. Géographie physique et Quaternaire, 38: 217-228. 
Rousseau, L., 1996. Étude stratigraphique de palses et de plateaux palsiques, rivière Boniface, Québec subarctique. M.A. thesis, Université Laval, Département de géographie, $92 \mathrm{p}$.

Salmi, M., 1970. Investigations on palsas in Lapland Finnish, p.143-153. In Ecology of the subarctic regions. Proceedings of the Helsinki Symposium 1966, UNESCO, Paris.

Savigny, K.W. and Morgenstern, N. R., 1986. Geotechnical conditions of slopes at a proposed pipeline crossing, Great Bear River Valley, Northwest Territories. Canadian Geotechnican Journal, 23: 490-503.

Seppälä, M., 1972. The term "palsa". Zeitschrift für geomorphologie, 16: 463. 1986. The origin of palsas. Geografiska Annaler, 68A: 141-147.

1988. Palsas and related forms, p. 247-278. In M.J. Clark, ed., Advances in Periglacial Geomorphology. John Wiley.

Shur, Y., 1988. The upper horizon of permafrost and thermokarst (In Russian). USSR Academy of Sciences, Siberian Branch, Novosibirsk, 209 p.

Smith, S. L. and Williams, P.J., 1990. Ice lens orientation around a chilled buried pipe. Proceedings, Fifth Canadian Permafrost Conference, Centre d'études nordiques, Université Laval, Nordicana 54: 83-87.

Smith, S.L. and Williams, P.J., 1995. Ice lens formation at a silt-sand interface. Canadian Geotechnical Journal, 32: 488-495.

Sone, T. and Takahashi, N., 1993. Palsa formation in the Daisetsu Mountains, Japan. Proceedings, Sixth International Permafrost Conference, Beijing, China, 2: 1231-1234.

Spolanskaya, N.A. and Evseyev, V.P., 1973. Domed-hummocky peatbogs of the northern taiga in western Siberia. Biuletyn Peryglacjalny, 22: 271-283.
Stuiver, M. and Pearson, G.W., 1993. High-precision bidecadal calibration of the radiocarbon time scale, AD 1950-500 BC and 2500-6000 BC. Radiocarbon, 35: 1-23.

Taber, S. 1929. Frost heaving. Journal of Geology, 37: 428-461. 317

1930. The mechanics of frost heaving. Journal of Geology, 38: 303-

Van Vliet-Lanoë, B., 1982. Structures et microstructures associées à la formation de glace de ségrégation: leurs conséquences, p. 116-122. In Proceedings, Fourth Canadian Permafrost Conference, Roger Brown Memorial Volume.

1985. Frost effects in soils. p. 117-158. In J. Boardman, ed., Soils and Quaternary landscape evolution. John Wileys \& Sons.

Washburn, A.L. 1983. What is a palsa? p. 34-47. In H. Poser and E. Schunke, ed., Mesoformen des reliefs im Heutingen periglazialraum. Göttingen. Mathematisch, Physikalische Klasse, Dritte folge nr. 35.

Worsley, P., Gurney, S.D. and Collins, P.E.F., 1995. Late Holocene "mineral palsas" and associated vegetation patterns: A case study from lac Hendry, northern Québec, Canada and significance for European Pleistocene thermokarst. Quaternary Science Reviews, 14: 179-192.

Zoltai, S.C., 1972. Palsas and peat plateaus in central Manitoba and Saskatchewan. Canadian Journal of Forest Research, 2: 291-302.

Zoltai, S.C. and Tarnocai, C., 1971. Properties of a wooded palsa in northern Manitoba. Arctic and Alpine Research, 3: 115-129. 